\title{
Pendidikan Islam Bagi Perempuan Indigenus Indonesia
}

\author{
Wildan Nuril Ahmad Fauzi'; Seka Andrean ${ }^{2}$ \\ 1,2Universitas Islam Negeri Sunan Kalijaga Yogyakarta \\ 1wildannufa12@gmail.com, 2sekaandrean28@gmail.com
}

\begin{abstract}
Since a long time ago the position of women became second class in the view of society. Not only in obtaining social status, but they also get this discrimination in health and education. This paper aims to discuss some of the things that become unease about Islamic education received by women. Although many Islamic leaders are well known, unfortunately, the drivers of women's Islamic education in Indonesia are very difficult and rare to find. This research uses library research using the philosophical approach. Data collection techniques used in articles are by documentation techniques that collect data material in the form of sources of books in the library, articles related to writings related to research. The results showed that women's standing is needed and movement proves directly through various things and various fields. The establishment of a girls' early childhood school, to build a university-based on Islam that combines it with general science, can open the face of women as a figure worthy to be recognized the greatness of Islamic Education received by these women contains a variety of knowledge that can improve their position and position as a mother and as a wife.
\end{abstract}

Keywords: Islamic Education, Women, Indigenous

\begin{abstract}
Abstrak
Sejak dulu kedudukan perempuan menjadi second class dalam pandangan masyarakat. Tidak hanya dalam mendapatkan kedudukan secara status sosial, diksriminasi ini juga mereka dapatkan dalam kesehatan dan juga Pendidikan. Dalam tulisan ini bertujuan untuk membahas beberapa hal yang menjadi kegelisahan mengenai pendidikan Islam yang diterima oleh perempuan. Walaupun banyak para tokoh Islam yang terkenal, sayangnya penggerak pendidikan Islam perempuan di Indonesia sangatlah sulit dan jarang untuk ditemukan. Penelitian ini menggunakan library research dengan menggunakan pendekatan filosofis. Teknik pengmpulan data yang digunakan dalam artikel adalah dengan teknik dokumentasi yaitu mengumpulan bahan data berupa dari sumber buku-buku yang ada di perpustakaan, artikel-artikel yang berbuhungan dengan tulisan-tulisan terkait dengan penelitian. Hasil penelitian menunjukkan bahwa kedudukan perempuan dibutuhkan trobosan dan gerakan membuktikan secara langsung melalui berbagai hal dan berbagai bidang. Pendirian sekolah diniyah putri, hingga membangun universitas berbasis agama Islam yang menggabungkannya dengan ilmu pengetahuan umum, mampu membuka wajah perempuan sebagai sosok yang patut untuk diakui kehebatannya Pendidikan Islam yang diterima oleh para kaum perempuan ini memuat berbagai macam ilmu pengetahun yang mampu meningkatkan posisi dan kedudukannya sebagai ibu dan sebagai seorang istri.
\end{abstract}

Kata Kunci: Indigenus, Pendidikan Islam, Perempuan 


\section{A. Pendahuluan}

Pendidikan merupakan topik pembahasan yang selalu memuat hal-hal menyegarkan untuk dibahas dan diamati oleh berbagai kalangan. Selain karena hampir setiap orang pernah merasakan pendidikan baik itu pendidikan formal, informal maupun non formal yang mana sering salah diartikan bahwa, pendidikan sama halnya dengan sekolah atau sering kita pahami sebutan ini sebagai lembaga pendidikan formal saja. Masyarakat dan dunia menilai bahwa pendidikan merupakan alat, jalan maupun wadah yang dianggap "membuat sukses" dan pandai setiap orang yang mengenyamnya. Berbagai lembaga pendidikan saat ini berlomba-lomba untuk menciptakan sekolah elit dan bergengsi. Sehingga orang-orang yang dapat mengenyam pendidikan tersebut hanyalah beberapa kaum tertentu yang dianggap "mampu" secara finansial dan intelektual.

Diskriminasi di dalam dunia pendidikan saat ini lebih kepada kemampuan finansial dan intelektual. Hal ini tentunya masih menjadi perbincangan karena ketidakadilan dalam pendidikan telah terjadi bahkan sebelum Indonesia merdeka dan masih berada di bawah penjajahan kolonial Belanda yang menduduki Indonesia hingga 350 tahun. Yang membedakannya adalah diskriminasi pendidikan yang saat itu terjadi tidak hanya sebatas kalangan bangsawan dan kalangan petani saja. Akan tetapi lebih kepada isu gender dan perbedaan anggapan mengenai kewajiban dan hak laki-laki serta perempuan mengenyam pendidikan adalah dua hal yang dianggap berbeda.

Lembaga pendidikan formal di Indonesia telah ada sejak zaman penjajahan Jepang dan juga Belanda. Namun karena Belanda menjajah begitu lama hingga 350 tahun, maka sistem pendidikan yang mereka bangun seperti mengakar dalam kehidupan rakyat Indonesia. Belanda membangun beberapa lembaga pendidikan formal seperti HIS (Hollandsch Inlandsche School) yakni Sekolah Dasar bagi pribumi, dimana bahasa pengantar yang digunakan adalah bahasa Belanda. MULO (Meer Uitgebreid Lager Onderwijs) Sekolah Menengah, serta AMS (Algemeene Middelbare School) yaitu Sekolah Atas (Poesponegoro, 2008, p. hlm) 
Sayangnya lembaga-lembaga pendidikan yang dibangun oleh Belanda ini hanya dikhususkan kepada para pribumi dengan darah bangsawan seperti keluarga kerajaan, para pejabat, atau orang-orang pribumi yang memiliki kedudukan sebagai antek-antek Belanda yang dipandangan hormat. Diskriminasi ini terjadi karena rendahnya pandangan kaum kolonial ketika itu kepada para pribumi Indonesia yang dianggap miskin, kumuh dan buruk. Tidak hanya disini saja, diskriminasi yang diterima oleh para siswa kaum bangsawan yang mengikuti lembaga pendidikan Belanda pun tidak lepas dari ketidakadilan. Pribumi dianggap kurang pintar, serta tidak mampu mengikuti perkembangan otak-otak kaum bangsawan Eropa.

Bahkan kaum perempuan mendapat perlakuan dikriminasi yang paling buruk dibandingkan laki-laki dalam hal pendidikan. Perbedaan pandangan sosial terhadap kedudukan perempuan seperti halnya budaya yang tidak dapat dipisahkan dari kehidupan pribumi kala itu. Tidak hanya dalam pendidikan, mereka menerima berbagai macam ketidakadilan bahkan di dalam keluarga maupun kehidupan rumah tangga. Perempuan dipandangan sebagai makhluk lemah yang tidak dapat bersaing dalam kehidupan ganas di luar rumah. Tugas pokok bagi perempuan adalah memasak, mengurus anak serta membersihkan rumah dan mencuci segala perlengkapan kotor. Tiga kata yang sering didengar sebagai tugas seorang perempuan adalah "Macak, Masak. Manak". Maksudnya adalah tugas perempuan hanyalah sebatas Berdandan untuk keluarganya, Memasak dan berkecimpung di dapur sebagai tugasnya, serta melahirkan seorang anak yang akan menjadi penerus silsilah keluarga. Dengan kata lain, tugas perempuan adalah berkembang biak.

Munculnya beberapa tokoh perempuan yang berperan penting dalam perkembangan status sosial perempuan dalam kehidupan masyarakat seperti R.A Kartini yang merupakan seorang putri bangsawan ketika itu tidak mampu merubah banyak pandangan masyarakat terhadap perempuan. Hingga saat ini di abad ke dua puluh satu, masih terdapat beberapa masyarakat yang menganggap rendah status sosial perempuan yang sebenarnya. Di desa-desa tertentu, menganggap bahwa anak perempuan tidak perlu melanjutkan pendidikan hingga kuliah, karena itu tidak perlu. 
Ada pula masyarakat yang beranggapan bahwa perempuan tidak boleh pergi terlalu jauh untuk merantau dan mendapatkan pekerjaan karena itu adalah hal yang tidak baik. Perempuan pulang kerja pada malam hari adalah kegelisahan yang menyebabkan aib dan memalukan bagi keluarganya. Pandangan-pandangan ini tentunya tidak akan mudah dilepaskan dari lapisan kehidupan masyarakat kita, khususnya desa-desa yang masih berpegang teguh terhadap nilai-nilai sosial yang kental.

Pendidikan formal saja tentunya sangat sulit didapatkan oleh para kaum perempuan ketika itu, lalu bagaimanakah mereka akan menerima pendidikan Islam dalam kehidupan sehari-hari sedangkan mayoritas agama pribumi ketika itu adalah beragama Islam. Ketika kita menilik sejarah mengenai masuknya Islam ke Indonesia pada Abad ke-7 Masehi, Islam begitu mudah masuk ke dalam relung kehidupan masyarakat pribumi yang masih berkepercayaan Hindhu dan Budha. Cara-cara yang dibawa oleh para saudagar dari Persia dan Gujarat tentunya memberikan warna baru bagi kehidupan religius serta spiritual pribumi Indonesia. Melalui perdagangan, pernikahan serta aturan-aturan dalam Islam yang mudah dipahami serta memberikan makna yang baik, tak alang banyak pribumi menerima Islam dengan cara yang lebih mudah.

Islam sebagai sebuah agama tentunya memiliki kaidah-kaidah serta aturan-aturan yang harus dilaksanakan oleh pemeluk-pemeluknya. Islam tidak hanya sebagai sebuah simbol formalitas bahwa seseorang telah beragama, tetapi lebih kepada kepercayaan kepada Allah yang Esa (Akidah), Taat dalam menjalankan perintahnya dan menjauhi larangannya (Ibadah), serta bersikap baik terhadap diri sendiri dan orang lain sebagai buah dari kepercaayan (Akhlak). Untuk mengetahui semua itu pribumi harus belajar kepada sang ahlinya agar diri mereka menjadi mukmin yang beribadah dengan ilmu, tidak hanya kosong tanpa tuntunan.

Hadirnya sosok para wali songo yang menyebarkan dan mengajarkan Islam kepada masyarakat pribumi dengan membangun berbagai macam madrasah, pondok pesantren, hingga belajar dalam sebuah surau-surau, langgar maupun masjid-masjid melalui sebuah kajian dan ta'lim merupakan 
sebuah perjuangan awal pendidikan Islam di Indonesia. Namun pengajaran ini lebih banyak diberikan kepada kaum laki-laki saja. Karena perempuan dianggap tidak aman dan tidak baik untuk keluar dari rumah serta meninggalan kewajiban dan pekerjaannya. Selain itu, perempuan merasa malu apabila harus berada dalam satu tempat dengan para laki-laki lainnya.

Dalam artikel ini tentunya penulis akan membahas beberapa hal yang menjadi kegelisahan kita mengenai pendidikan Islam yang diterima oleh perempuan pribumi ketika itu. Walaupun banyak para tokoh Islam yang terkenal, sayangnya penggerak pendidikan Islam perempuan di Indonesia sangatlah sulit dan jarang untuk ditemukan. Disinilah penulis akan sedikit menggali informasi mengenai pendidikan Islam bagi perempuan Indigenious Indonesia.

\section{B. Metode}

Analisis metode dalam jurnal ini menggunakan library research dengan menggunakan pendekatan filosofis (mengkaji pendidikan islam bagi perempuan indigenious indonesia). Teknik pengmpulan data yang digunakan dalam artikel adalah dengan teknik dokumentasi yaitu mengumpulan bahan data berupa dari sumber buku-buku yang ada di perpustakaan, artikel-artikel yang berbuhungan dengan tulisan-tulisan terkait dengan penelitian, serta dikumpulkan dan diambil dan diintisarikan serta dikaitkan dengan objek kajian (Arikunto, 2013).

\section{Hasil dan Pembahasan}

\section{Pendidikan Perempuan}

Terbukanya kesadaran mengenai pendidikan bagi kaum perempuan tentunya dimulai ketika Indonesia membuka dirinya dengan kedatangankedatangan orang-orang asing yang membawa perubahan-perubahan bagi masyarakat. Gagasan tentang kemajuan mulai tumbuh seperti yang dijelaskan oleh Marwati di dalam bukunya Sejarah Nasional Indonesia, dimana hal ini muncul pada abad ke-21 dengan pelopor terkenanya yakni Raden Ajeng Kartini sebagai penggagas akan pemikirannya yang dituliskan di dalam surat- 
suratnya kepada sahabat Belanda yang kemudian dituliskan dan diedit oleh J.H Abendanon pada tahun 1912 dengan judul yang hingga saat ini menjadi kajian-kajian dalam bidang emansipasi perempuan "Habis Gelap Terbitlah Terang".

Kekhawatiran Kartini ini bermula dari bagaimana perempuanperempuan di Indonesia kala itu sungguh terikat kuat dengan budaya serta adat istiadat setempat yang bersifat mengekang kreatifitas serta potensi bagi perempuan. Perempuan dianggap sebagai aset yang mana haruslah benarbenar dijaga dan tidak diperkenankan melakukan segala bentuk kegiatan yang dapat dilakukan oleh kaum laki-laki seperti, bekerja, belajar, atau bahkan keluar rumah. Pendidikan bagi kaum perempuan ketika itu dianggap sebagai sebuah bentuk pelanggaran.

Hal ini tidak serta merta terjadi dalam kehidupan sehari-hari para perempuan, bahkan mereka tidak diijinkan untuk keluar rumah. Bahkan para perempuan tidak diperkenankan untuk memilih sendiri calon suami yang baik bagi mereka. Karena masyarakat pribumi ketika itu percaya bahwa untuk memilih seorang suami yang tepat, dibutuhkan pengalaman dari orang yang lebih matang, tua dan dihormati yakni orang tua.

Dalam suratnya kepada Prof dan nyonya F.K Anton di Jena pada tanggal 4 Oktober 1904 Kartini menuliskan, “Apabila kami dengan sangat meminta pendidikan dan pengajaran bagi gadis-gadis bukanlah sekali-kai karena kami hendak menjadikan anak-anak perempuan sebagai saingan orang laki-laki dalam perjuangan hidup ini, melainkan karena kami hendak menjadikan perempuan itu lebih cakap melakukan kewajibannya yaitu kewajiban yang diserahkan oleh alam sendiri kedalam tangannya yakni menjadi ibu, pendidik manusia pertama".(Poesponegoro, 2008)

Didalam surat tersebut Kartini menyampaikan bahwa pendidikan bagi kaum perempuan sendiri merupakan sebuah alat yang mampu meningkatkan potensi jadi dirinya untuk mendidik anak dan merawat keluarga. Pendidikan yang baik bagi seorang ibu tentunya akan berdampak terhadap tumbuh dan kembang anak karena anak-anak yang hebat akan terlahir dari para ibu yang hebat. Bagi Kartini, pendidikan perempuan tidak akan membuat perempuan 
menjadi tinggi kedudukan dan posisinya di dalam masyarakat seperti halnya kaum laki-laki. Tapi sejatinya dengan pendidikan ini akan membuat para perempuan memiliki bekal dan landasan tanpa meninggalkan peran dan posisinya terhadap kewajiban yang sejatinya diemban oleh perempuan.

Peningkatan pendidikan dapat membekali dan memperbaiki perempuan untuk berkiprah dalam masyarakat yang tiada hentinya bergerak maju. Dengan mempertimbangkan penyebab utama diperolehnya peran dan status perempuan dalam masyarakat, tersedianya kesempatan untuk mendapatkan pendidikan (yang sama antara pria dan perempuan) lebih memberi peluang untuk berperan sosial. (Mulyani Sumantri, 2007) Membekali perempuan dengan pendidikan sejatinya akan memberikan manfaat sosial karena peran perempuan akan memberikan masukan dan dorongan bagi terciptanya gagasan-gagasan penyelesaian masalah-masalah yang ada dimasyarakat yang terkadang bagi kaum laki-laki perkara ini cukup sulit untuk diselesaikan.

Berdasarkan hasil penelitiannya Smock berkesimpulan bahwa "semakin tinggi" pendidikan yang diperoleh perempuan akan semakin tinggi pula kemampuannya untuk berbagi otoritas dalam keluarga; lebih mendapat kesempatan untuk berkelanjutan dalam pekerjaan dan jabatan profesional, dan dapat berpartisipasi lebih luas dalam kegiatan sosial dan politis.(Smock, 1997)

Pendidikan yang diterima bagi kaum perempuan akan memberikan beberapa manfaat seperti : (a) Menjadikan perempuan lebih berwawasan dan berkemampuab khususnya membantu memecahkan persoalan dalam keluarga yang tidak dapat diselesaikan secara sendiri. (b) Memberikan pendidikan-pendidikan mengenai keterampilan maupun kemampuan dasar tentang tata cara mendidik maupun mengasuh anak. (c) Perempuan yang memiliki ilmu dan kepandaian akan dipandang sebagai perempuan bermartabat dan anggun tanpa melupakan kodratnya sebagau seorang ibu, anak maupun istri. (d) Pendidikan bagi kaum perempuan tentunya akan memberikan wawasan dalam hal-hal yang berhubungan dengan suami dan 
istri, khususnya dalam rumah tangga, hingga kesehatan dimana terkadang perempuan merasa enggan dan malu untuk mengutarakannya.

\section{Kedudukan Perempuan dalam Pandangan Islam}

Persoalan mengenai kedudukan perempuan telah menjadi polemik yang cukup panjang. Sejarah mengungkapkan bahwa posisi perempuan sebagai second class telah terjadi puluhan bahkan ratusan tahun yang lalu. Tidak hanya di Indonesia, banyak sejarah yang tertuliskan disetiap negara bahwa posisi dan kedudukan perempuan sangatlah tidak diuntungkan jika dibandingkan dengan kaum laki-laki. Seperti pada masa jahiliyah Arab bahwa anak perempuan dianggap kurang berguna dibandingkan anak laki-laki. Anak perempuan dianggap makhluk lemah sehingga tidak jarang para budak yang dipelihara kebanyakan adalah perempuan. Dahulu kala jika suatu keluarga melahirkan anak perempuan, maka kedepannya kehidupan keluarga tersebut akan sial. Tentunya jika mengingat sejarah ini, tertuliskan mengenai kisah Umar bin Khattan sebelum beliau masuk Islam telah membunuh dan mengubur anak perempuannya secara hidup-hidup.

Tidak berbeda dengan Arab, negara-negara seperti Yunani, India bahkan Cina juga menempatkan perempuan sebagai kelas dua. Seperti kehidupan di Cina, anak perempuan dianggap sebagai manusia yang tidak boleh memiliki kekuatan berupa chi yang lebih besar dibandingkan dengan laki-laki. Perempuan tidak boleh bertarung, berkelahi, berperang hingga membela dirinya dari kekerasan. Apabila dilanggar maka para perempuan ini akan mendapatkan hukuman atas perbuatannya. Para perempuan hasil dari suatu wilayah yang kalah berperang akan dijadikan sebagai budak-budak penguasa untuk diperjual belikan, mengabdi dan bekerja tanpa dibayar hingga menjadi gundik ataupun selir.

Dalam doktrin Yahudi perempuan dipandang sebagai makhluk yang terkutuk karena telah menggoda Adam untuk memakan buah khuldi yang dilarang oleh Allah sehingga mengakibatkan mereka dikeluarkan dari surga. Selain itu di dalam kitab Taurat perempuan dinyatakan sebagai makhluk yang jahat bahkan lebih jahat dari maut (Maulana Muhammad Zaferuddin, 2004, h. 
21). Agama Hindu berpendapat bahwa wabah kematian, neraka, racun dan api lebih baik daripada perempuan. Sedangkan Agama Nasrani memandang perempuan sebagai makhluk rendah dan hina. Karena perempuan dianggap sebagai sumber bencana dan kejahatan.(Ahmad Satori Ismail, 2000)

Pandangan mengenai kedudukan perempuan sebelum Islam datang menempatkannya kepada kelas rendah yang tidak diakui. Namun berbeda dengan agama Islam yang mengembalik hak-hak perempuan sebagai seorang makhluk yang pantas dilindungi, dikasihi dan dicintai. Islam memberikan pandangan bahwa kedudukan perempuan dalam Islam sangatlah mulia. Karena pendidikan pertama yang diberikan kepada seorang anak adalah melalui perempuan. Hingga Nabi Muhammad sendiri menyebutkan bahwa surga seorang anak berada di bawah telapak kaki ibu. Bahkan Rasulullah Saw. menyebutkan nama ibu sebanyak tiga kai untuk orang yang patut dihormati terlebih dahulu yang mana dilanjutkan dengan Ayah.

Islam memandang perempuan sebagai ibu dari umat. Artinya perempuan-perempuan yang sholehah tentunya akan melahirkan umat-umat generasi yang berakhlakul karimah. Nabi memperkenalkan hak waris bagi perempuan, ketika perempuan hanya dianggap sebagai objek yang diwariskan. Kemuliaan perepmpuan dalam pandangan Islam kemudian dikenalkan pula oleh Nabi melaui mahar yang wajib diterima oleh perempuan sebagai hadiah atas perkawinan mereka. Makna mahar tidak dianggap sebagai materi untuk "membeli" perempuan sebagai seorang istri. Rasul mengenakan makna mahar sebagai sebuah hadiah kepada perempuan karena telah menerima pernikahan yang diajukan.

Rasulullah mengajarkan kepada umatnya akan kedudukan perempuan dalam tatanan hidup manusia. Seperti peran Khadijah dalam membantu dakwah Nabi Muhammad, hingga Aisyah yang menjadi seorang perawi Hadist Perempuan yang memiliki kecakapan dan kecerdasan dalam menyampaikan ilmu-ilmu serta menyelesaikan berbagai permasalahan di dalam kehidupan umat Islam setelah peninggalan Nabi Muhammad. Walaupun setelah sepeninggal Rasululllah pemikiran mengenai kedudukan perempuan dalam tatanan hidup masyarakat seperti kembali untuk dinomor duakan, akan tetapi 
makna-makna yang telah Islam ajarkan tetap memberikan posisi dan kedudukan yang terhormat kepada perempuan.

\section{Pendidikan Islam bagi Perempuan Indigenious Indonesia}

Setelah membahas mengenai pendidikan bagi perempuan hingga kedudukan perempuan di dalam Islam, saat ini mari kita selami mengenai pendidikan Islam bagi perempuan Indegenious Indonesia. Seperti yang telah dijelaskan di awal bahwa pendidikan dan perempuan merupakan dua hal yang dulunya sulit untuk direalisasikan. Lalu bagaimanakan dengan pendidikan Islam yang seharusnya diterima oleh perempuan sebagai seorang umat, makhluk serta manusia yang beragama dan berke-Tuhanan yakni Allah Swt. Karena tentunya realisasi sebuah agama tidak hanya diajarkan melalui doktrin-doktrin teoritis tanpa sebuah contoh praktinya di dalam kehidupan sehari-hari.

Seperti yang telah dijelaskan sebelumnya bahwa kedudukan perempuan di dalam Islam sangatlah mulia. Hal ini telah diajarkan oleh Rasulullah cara-cara untuk memuliakan perempuan dengan baik sesuai porsinya. Namun setelah Rasul wafat, beberapa kalangan masyarakat kemudian melupakan bahwa seyogyanya perempuan adalah sama dengan laki-laki. Dalam proses pendidikan Islam di Indonesia sendiri, pendidikan Islam telah diajarkan secara menyeluruh dari langgar, sekolah, ta'lim hingga pengajian-pengajan yang diadakan oleh kalangan ulama, kiyai, hingga ustadz. Sayangnya pendidikan Islam ini lebih banyak bahkan hampir semuanya ditujukan dan diikuti oleh kaum laki-laki saja. Hal ini dikarenakan bahwa ketika laki-laki dan perempuan berada dalam satu tempat majlis ta'lim dianggap kurang sopan dan tidak memenuhi etika.

Kemudian muncullah tokoh-tokoh perempuan dalam penggerak pendidikan Islam di Indonesia. Tentunya gerakan dan pemikiran mereka muncul atas realita yang terjadi di masyarakat mengenai kurang dan minimnya pendidikan Islam yang selayaknya diterima oleh berbagai kalangan dalam lapisan masyarakat termasuk perempuan. 
Nama Rahmah El-Yunusiya mencuat setelah pemikiran dan gagasannya untuk mendirikan madrasah bagi perempuan-perempuan ditanah Padang Panjang. Gagasannya ini tidak serta merta keluar tanpa jalur yang pasti. Pengaruh lingkungan keluarga memberikan sumbangsih besar terhadap gagasan dan pemikiran Rahmah El-Yunusiyah dalam mendirikan madrasah bagi perempuan. Hal ini dikarenakan Rahmah El-Yunusiyah lahir dari kalangan ahli ilmu dimana ayah dan kakaknya memiliki sekolah Diniyah (sekolah yang mengajarkan ilmu pendidikan Islam setiap malam hari) yang diberikan nama Diniyah School.

Sebagai seorang anak dari keluarga terpandang yang mendapatkan pendidikan dari keluarganya, membuat Rahmah miris terhadap kondisi kaum perempuan masa itu. Hingga pada tahun 1923 tepatnya pada tanggal 1 November 1923 ia mendirikan sekolah khusus perempuan yang diberi nama Diniyah School Putri atau Madrasah Diniyah li al-Banat yang bertempat di Masjid Pasar Usang (Isnani, 2016). Madrasah ini didirkan Rahmah karena ia melihat realita selama menjadi siswa di Diniyah School yang didirkan oleh kakaknya bahwa ia merasa tidak puas dengan sistem koedukasi yang mana kurang memberikan penjelasan terbuka kepada siswa puteri mengenai persoalan khusus perempuan.

Berbagai rintangan dihadapai Rahmah dalam membangun sekolah untuk perempuan. Salah satunya adalah ketika Rahmah baru saja membangun sekolahnya dengan bangunan yang permanen, terjadi sebuah kebakaran yang meluluhlantakan bangunan seluruh bangunan. Sehingga mau tidak mau Rahmah harus kembali mencari dan mengumpulkan dana untuk membangun sekolahnya kembali. Beberapa kali Rahmah mendapatkan tawaran dari pihak Belanda untuk menerima donasi dengan syarat kurikulum di sekolah tersebut haruslah sesuai dengan yang diinginkan oleh pihak Belanda. Namun dengan kesungguhan dan kegigihan tentunya Rahmah bersikeras menolah tawaran yang diajukan Belanda karena ia tidak ingin ada campur tangan pihak kolonial di dalam pendidikan yang ia bangun.

Menurut beberapa sumber, pada awalnya sekolah diniyah puteri ini didirikan untuk memberantas buta huruf bagi kalangan perempuan Minang 
ketika itu khususnya bagi ibu-ibu rumah tangga yang menyesa tidak dapat bersekolah dan belajar membaca (Ajisman, 2017). Di samping itu diajarkan pula ilmu-ilmu agama seperti Akidah, Fiqh, Ibadah, Sejarah, Ilmu Al-Quran dan Hadist serta pendidikan keterampilan seperti menjahit dan menenun dan pendidikan kesehatan bagi para perempuan serta ibu-ibu rumah tangga. Untuk memberikan pembelajaran dan pendidikan mengenai kesehatan ini Rahmah El-Yunusiyah menuntut ilmu di RSU Kayu Tanam dan mendapatkan ijazah serta izin praktek bidan dari dokter. Dalam memberikan pendidikan formal (sekolah), Perguruan Diniyah Puteri mengintegrasikan pengajaran ilmu-ilmu agama dan ilmu-ilmu umum secara klasikal, serta memberi pelajaran kemahiran. Selama pendidikan formal tersebut berlangsung semua pelajar diawasi oleh guru perguruan, dan kepada mereka dikenakan disiplin sekolah yang ketat baik di dalam kelas maupun di luar kelas (Ajisman, 2017).

Pendidikan Islam bagi para perempuan-perempuan pribumi yang dilakukan oleh Rahmah tentunya mendapatkan berbagai rintangan dari berbagai kalangan. Akan tetapi perjuangannya tidak pernah berhenti karena menganggap bahwa kaum perempuan berhak mendapatkan pendidikan keislaman secara khusus tentang perempuan yang mana tidak mereka dapatkan dalam setiap kegiatan ta'lim dan pengajian yang dilakukan di setiap langgar. Salah satu tujuan pendidikan Islam ini bagi perempuan adalah untuk memahami hal-ha bersifat "keperempuanan" yang diajarkan di dalam agama Islam.

\section{Kesimpulan}

Raden Ajeng Kartini sebagai tokoh emansipasi perempuan secara umum, memperjuangkan hak-hak kaumnya dengan cara-cara yang mengesankan. Begitu pula yang dilakukan oleh ibunda Rahmah El-Yunusiyah dalam memperjuangkan pendidikan Islam bagi perempuan-perempuan di tanah Minang. Pendirian sekolah diniyah putri, hingga membangun universitas berbasis agama Islam yang menggabungkannya dengan ilmu pengetahuan umum, mampu membuka wajah perempuan sebagai sosok yang patut untuk diakui kehebatannya. Pendidikan ini diharapkan berkontribusi 
besar dalam segala bidang pembangunan. Pendidikan Islam yang diterima oleh para kaum perempuan ini memuat berbagai macam ilmu pengetahun yang mampu meningkatkan posisi dan kedudukannya sebagai ibu dan sebagai seorang istri. Pendidikan mengenai ilmu Akidah, Fiqh, Al-Qur'an serta Hadist, serta ilmu-ilmu lainnya seperti ilmu kesehatan, ilmu keterampiran menjahit dan menenun tentunya tidak akan menjadi senjata untuk menjatuhkan kaum laki-laki sebagai makhluk yang dapat dikalahkan.

\section{DAFTAR PUSTAKA}

Ajisman, D. (2017). Tokoh Inspiratif Bangsa. Jakarta: Direktorat Jendral Kebudayaan Kementrian Pendidikan dan Kebudayaan.

Arikunto, S. (2013). Prosedur Penelitian Suatu Pendekatan Praktis. Jakarta: Rineka Cipta.

Hamruni. (2004). Pendidikan Perempuan dalam Pemikiran Rahmah El Yunusiyah. Jurnal Kependidikan Islam Volume. 2 No. 1, Februari, 105-125.

Ismail, Ahmad Satori. (2000). Fiqih Perempuan dan Feminisme" dalam Mansor Fakih (ed.). Membincang Feminisme: Diskursus Gender Perspektif Islam. Surabaya: Risalah Gusti.

Isnani, R. L. (2016). Ulama Perempuan dan Dedikasinya. Jurnal Pendidikan Agama Islam, Vol. 4 No.

Poesponegoro, M. D. (2008). Sejarah Nasional Indonesia (Zaman Kebangkitan Nasional dan Masa Hindia Belanda) Jilid 5. Jakarta: Balai Pustaka.

Tim Pengembang Ilmu Pendidikan UPI. (2007). Ilmu dan Aplikasi Pendidikan (Bagian IV: Pendidikan Lintas Bidang. Bandung: Imtima.

Zaferuddin, Maulana Muhammad. (2004). Misi Seksual Islam, Melahirkan Kehormatan Diri dan Kesucian. Jakarta: Sahara Publisher. 
